scholars without impediment. On the question of the public policy of the institution for which they work, however, civil service employees are less than free. In the past several months, many among the museum's staff have sympathized with many of the complaints made against their institution, but have been gagged. The problem is not novel. Scientists working in defence establishments may, for example, differ from official policy on defence procurement, but may be unable to say so publicly. Those working on the development of the Anglo-French supersonic aircraft Concorde may have considered at the time that the project would be a waste of money and resources, and would by now have been justified by events. In such circumstances, however, it is understandable (if reprehensible) that laboratories should require their employee-scientists to keep their silence. The case for insisting on such a policy at an institution such as a natural history museum, whose public reputation stems from the supposed academic independence and integrity of its members, is by comparison non-existent. It is to be hoped that the museum's trustees will now give this problem the attention it deserves, and urgently. For the correspondence of the past months shows that there is a great depth of seemly and legitimate professional interest in Darwinism, cladism and related matters. And it is not long until next April, when it will be time to mark the centenary of Charles Darwin's death.

\section{Too much government}

The British government has once again slipped into the trap of taking too detailed an interest in the management of technology, this time in the development of the British nuclear power programme. Last week, the Department of Energy published its reply (see page 398) to the Select Committee on Energy's report which, among other things, advocated that attention should be paid, even at this late stage, to the building of heavy water reactors on the Canadian pattern. In doing so, the committee was keeping faith with the traditions established by its predecessors (principally the now defunct Select Committee on Science and Technology) in hankering after reactor designs that nobody with direct responsibility for generating electricity wants to build. (Nearly a decade ago, the committee was pushing for the steam generating heavy water reactor, a complicated device using heavy water as a neutron moderator and pressurized ordinary water as a coolant, which was in 1977 discovered to be too complicated to fabricate.)

The Department of Energy rightly said last week that nothing has happened in the past four years to suggest that Canadian heavy water reactors would be economic in British circumstances, and thus rejected the committee's chief technical recommendation. As the department responsible for the Central Electricity Generating Board, the principal owner of reactors in the British electricity supply network, the department is well within its rights in making this opinion public. But it goes too far when it declares that the next thermal reactor ordered for the British network "should be the Pressurized Water Reactor". By this declarative statement of technical policy, the Department of Energy has committed the British government not merely to a technical policy that it (or its successor) may regret, but to a role in the management of technology that it should not be playing.

The circumstances are clear. The nationalized industry with a near-monopoly right to generate electricity south of the Scottish border is the Central Electricity Generating Board, much criticized by the Select Committee on Energy for its overoptimistic forecasts of electricity demand and for its imprecise calculations of the relative costs of generating electricity from different fuels. Constitutionally, the board has an unambiguous technical responsibility for deciding how best to generate electricity. If, with the passage of time, the board is found to be incompetent, either technically or in its economic judgements, the Department of Energy has a right, even a responsibility, to fire the board and appoint another. But if the department also sets itself up as the body that decides what kinds of reactors should be built, its freedom to exercise its own constitutional responsibilities must be compromised. Worse, the government itself, and not the generating board, will become the target for the torrent of complaint that will be mobilized at next year's public inquiry at the proposal to "recreate Three Mile Island in Suffolk" (for where the generating station is destined). The result will be that the government's essential quasi-judicial role as the arbiter between the generating board and public protesters will also be undermined. How can it be otherwise when the department in its reply to the select committee uses forms of words such as "the government believes"' that the next British reactor ordered should be a pressurized water reactor?

This complaint is not mere pendantry. Forms of words matter, and in this case all too clearly reveal that the Department of Energy has not clarified for itself its relationship with the electricity-generating industry. The result is that the department's announcement of the form of the public inquiry about the first British reactor of this type has a hollow ring. Last week's document says that the inquiry is to be "wide ranging", that documents describing the studies that will have been made of the safety of the British reactor should be published well in advance, and that objectors should have time in which to prepare their case. The department rejects the select committee's proposal that a time limit should be fixed for the inquiry. All this is sensible enough if the objective is to reconvert British public opinion to nuclear power. The snag is that the department, having announced in advance its "belief" in the generating board's plan, will be accused at the inquiry of being a prejudiced judge in the case. This is a surprising error for a government which, at its election two years ago, advocated that government should be less obtrusive.

\section{Over-civil servants}

The trouble with the British government's response last week to the inter-departmental review of the scientific civil service published nearly a year ago (see Nature 287,$264 ; 1980$ ) is that much of what it says has been said before. Yes, steps will be taken to help people recruited into the public service as scientists to move to administrative work. Yes, arrangements will be worked out to make the careers of those who stay as working scientists more interesting and challenging. Yes, steps will be taken to see whether government departments could make fuller use of scientists on short-term appointments. Yes, steps will be taken to define the roles of chief scientists in government departments (and then to ensure that these roles are carried out). Yes, steps will be taken to improve the literature handed out to potential recruits to the British scientific civil service (and departments will be asked to explain themselves to the Civil Service Department if they make a habit of recruiting highly qualified people to relatively lowly jobs). Yes, yes; the future will indeed be different from the past and better, more enlightened, more flexible, more challenging.

Brave words do not necessarily come true, as the negligible response of successive governments to the report of Lord Fulton's Royal Commission on the Civil Service more than a decade ago has shown. Briefly, however, the British civil service (and any other public service) has two overriding problems to solve in its relationship with scientists. First, how is the appalling lack of scientific understanding in the formulation of general policy to be made good? And how are those employed exclusively as scientists to be kept interested and alert? The simplest course would solve both problems. Let the recruitment of professional scientists (PhDs for example) to the public service be at the outset for an initial period of seven years. Let it be understood that those dispensed with at the end of this period are given a substantial gratuity, say a year's salary. And let it be understood that those kept on should either help to make policy or function as professional scientists, with the proviso that while they may be required confidentially to advise the departments that employ them on technical matters, they should be free to take part in the affairs of the intellectual professions that gave them skill (see above). 